\title{
8
}

\section{Turkey's Kurdish Problem: Borders, Identity, and Hegemony}

\author{
$\ddot{U}$ mit Cizre
}

Despite an increasing body of contemporary literature on it, there is still little understanding on the full dimensions of Turkey's Kurdish problem. Objective, creative, and critical scholarship is stunted by a long list of constraints. These include either ideological hostility or excessive empathy with the object of study as well as misrepresentations, distortions, and defensive impulses in both directions. But more importantly, in writing about the issue, social scientists face hard choices between popular perceptions and historical reality. Empirical data derived from opinion polls conducted with Turkish and Kurdish respondents add yet other elements of complexity to the full appreciation of the problem.

One such complexity is defining the territorial parameters of Kurdish nationalism. Most field surveys done or commissioned in the last three years by various civil societal organizations suggest that the majority of Kurdish respondents do not want an independent Kurdish state carved out of Turkey. ${ }^{1}$ Whether or not these studies gauge clear opinions or reflect

1 The PIAR-GALLUP poll conducted in 1994 with 1,000 respondents representing Turkish public opinion and 500 Kurds from urban and rural areas in the south-east shows that 51 per cent of the Kurds surveyed defined the problem as one of 'ruthless repression by the state' in the heavily Kurdish populated region of the south-east. Another 28.1 per cent perceived it as a question of social and economic deprivation. Whereas 6.4 per cent of the Kurds surveyed saw it as an issue of gaining autonomy within Turkish borders, only 4.3 per cent regarded it as an question of carving out a separate Kurdish state. While the overwhelming body of Kurds define the problem as a product of domestic mismanagement and not as an expression of a wish on the part of Kurds to set up an independent state so as to cause contraction of Turkish borders, 48.8 per cent (a plurality) of Turks see the problem to be caused by a terrorist movement which aims to divide Turkey PIARGALLUP 1994). The most serious survey evidence which combines empirical and conceptual data to understand and explain the roots and consequences of the Kurdish question from the viewpoint of Kurdish respondents, was published in July 1995. Being sponsored by a powerful and statefriendly economic interest group, the Union of Turkish Chambers of Commerce and Stock 


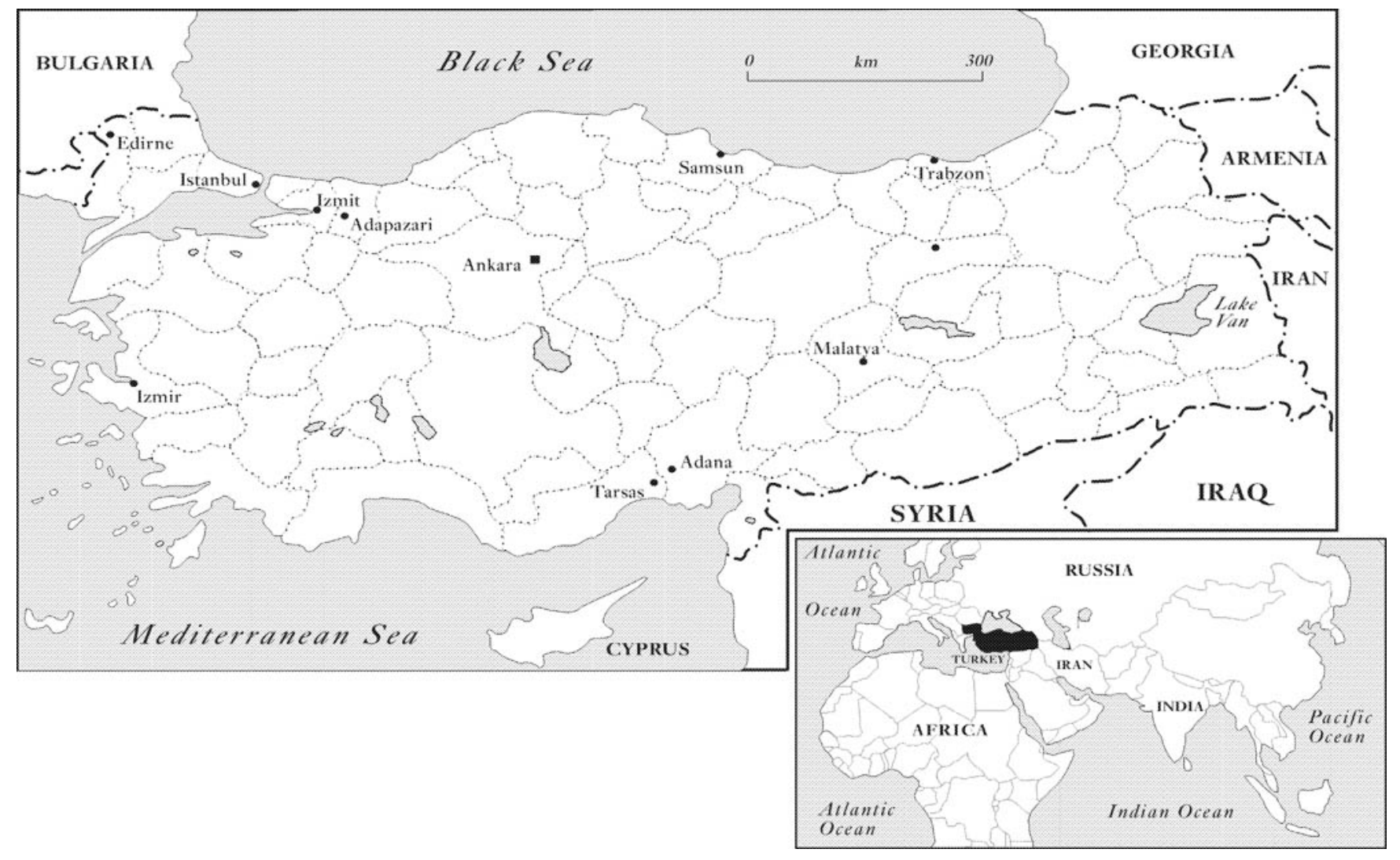


confused sentiments, the important point to note is that the perspectives of Turkish respondents surveyed lead us to believe that Kurdish nationalism is popularly conceived as a territory-aspiring, counter-national force challenging Turkey's political existence. ${ }^{2}$ This is in tune with the official presentation of the problem as one of threatening the ultimate criterion of Turkey's political being, its territorially circumscribed geography, 'the Turkish rectangle'. The non-Kurdish public does not seem impressed by the evidence of complex Kurdish sensibilities embedded in statistical figures. The root causes for this suspicion can be found in the problematic history of the interaction between the two communities. The harshness of the present armed conflict between the state security forces and the Kurdish Workers' Party (PKK) reinforces the belief that Kurdish nationalism is not a simple expression of discontent, but a movement that demands changing the boundaries of the Turkish entity to make room for an independent Kurdish state.

The former regional governor of the nine predominantly Kurdish southeastern provinces which are ruled under special emergency regime, Necati Bilican, echoed this historic suspicion quite openly, when he was quoted saying 'first they ask for innocent sounding cultural rights, like being allowed to speak Kurdish, which is no problem for us ... Then, it is a Kurdish television station, then cultural autonomy, then political autonomy. The end goal is to create a Kurdish state, which is something we will never allow' (Kinzer 1997). Whether the reader agrees with the substance of what Bilican says is less important than the analytical concern to note that once the issue is perceived in this way by members of the ruling élite, the official discourse moves

Exchange - the Turkish acronym being TOBB - the report created massive uproar in the media and shocked public opinion because it disclosed the empathy and alarm of a corporatist organization so intimately connected with government, on a taboo-like subject. The TOBB report was based on interviews with self-identified Kurds in three heavily Kurdish provinces in the south-east and three provinces in the south receiving heavy Kurdish migration. It sought to to elicit data on socioeconomic variables, and on the attitudes and opinions of respondents on the nature of the Kurdish problem, on identity, immigration trends, language, religion, and terrorism. It was built on interviewing 1,267 respondents in the said six urban centres-90.3 per cent of the sample is male and 9.7 per cent female. The importance of the report lay in its intentions and warnings. Seeking to understand the problem and find out the general principles for its solution, the report warned about the regime's responsibility for the current reality and invited the ruling élite to break the vicious circle. One significant finding of the TOBB study was about the territorial aspect of the Kurdish question: while 42.5 per cent of the respondents opted for a federal administrative structure, only 13 per cent sympathized with the idea of a completely independent Kurdish state. But when the respondents who opted for federalism were asked what they understood by federalism, they defined it as a structure that would allow for freer expression of cultural rights and conditions of living as a Kurd rather than a change in the political unity of the state. A third category of respondents who wished to see a cultural autonomy for Kurds without the break up of the existing state constituted 13 per cent, and associated it with the constitutional guarantees for cultural rights (TOBB 1995).

2 According to the PIAR-GALLUP poll cited in note 1,48 per cent of the Turkish respondents perceive the problem as a struggle to carve out land from Turkish territory. 
on to the non-negotiability of Turkey's territorial space, on the grounds of preserving Turkey's political life. Even to consider the negotiation of state boundaries in Turkish political syntax is thought to lead to 'wrong-sizing', because it is thought to end in a fatal contraction. This prospect, quite simply, is regarded as putting the life and existence of Turkey in danger.

One definition of the modern state goes straight to the heart of what the majority of Turkish people and state fear: 'the state does not have a territory, it is a territory' (Poggi 1990: 22). Obviously, this approach to defining the state oversimplifies the nexus among people, territory and state by identifying each with the other. It also fails to account for nation- and boundary-defying forms of power, loyalties and differences characteristic of the late modern age. Nevertheless, it strikes the right chord, harmonizing with the popular rejection of the negotiability of boundaries that would spell a death-warrant for the entire life and existence of the Republic. The commitment to this line of thinking is deeply rooted and overwhelming. The ultra-nationalist slogan of 'give land and be rid of' (ver kurtul), full of racist overtones, is an inverted form of the official stand and is not sincere. Where contestation over borders has become part of the international landscape, it may be difficult for Western scholarship to understand the depths of extreme nervousness evoked in Turkey by the issue of boundaries. All the more reason, therefore, for scholarly and critical inquiries into the past and present background against which official and popular discourse on boundaries has emerged and is sustained.

This essay will take the official and popular discourse on the idea of nonnegotiability of Turkey's boundaries as a given, and will also take it as read that the notion of boundaries is neither anti-political nor anti-social, and that it carries its own philosophical luggage shaped by history. The chapter has two basic objectives. One central concern is to reflect critically on the past and present sources of the Turkish discourse which links immutability of the national borders with existential questions. It is as a result of this posture that any 'adjustment in the size and shape of the state as a strategic response by elites to demands they face that may not be met within the existing borders' (Lustick and O'Leary 1996: 1) is rejected. In doing this, I will identify boundaries with two historical functions: celebration of the likeness of the natives and creation of a distinct political personality for that country by 'domestication of politics' (Wolin 1996: 33). While examining the former function will involve analysing and questioning the creation and construction of the 'hegemonic' idea of Turkey and Turkishness, explaining the latter function will take us to delineating the territorial conditions of existence for Turkey's democracy. Following in the footsteps of Sheldon Wolin who suggests that this latter function turns boundaries into metaphors of integration and exclusion, so that '.. . the reality cloaked in the metaphor of boundaries is the 
containment of democracy', the notion of Turkey's uncontestable borders will be linked with the justification of a certain democratic imaginary (Wolin 1996: 33). The second organizing theme of the essay is to establish the evolving nature of the expressions of Kurdish distinctiveness from a historical perspective. The terms of these expressions have been reconfigured at different time periods and contexts in interaction with the broader, Turkish, political environment.

\section{Borders as Bounding or Constituting the Nation? Turkey's Grand Right-Sizing of 1919-23 Precluded Further Right-Sizing}

Borders took precedence over other attributes of a nation-state in the creation of the Turkish Republic in 1923. There are two reasons why the territorial aspect of Turkish nationalism is most pronounced. The first is related to the memory of historical crises represented by the contractions of the Ottoman Empire preceding the setting up of the Republic. The other is grounded in the identity-driven preoccupation of the Republic that wishes to achieve a political personality distinct from the Ottoman past.

The new entity called Turkey came into existence by a form of rightsizing, that is by the contraction of the predecessor state, the Ottoman Empire. There were a series of right-sizings, contractions in the history of the Empire that are associated in Ottoman-Turkish memory with crisis and debacle: the Balkans and the Arab lands were lost through a series of defeats and withdrawals by Ottoman military and diplomatic power. The Anatolian rectangle was the only context for what was left of the Ottoman boundaries. The dismemberment of the Empire in the last century of its existence turned into a historical scar, redolent of humiliation and failure. The insecurity and anguish occasioned for the subjects of the Empire meant that the idea of contraction, therefore, became at worst a source of major trauma and fears in the popular and élite imagination, and at best, a measure of last resort. The memory of the involuntary Ottoman dismemberment dictated and justified the fundamental rules of Turkey's political life after independence. The habitual language of 'unity and integrity' (birlik ve bütünlïk), a popular parlance in politics, evokes this memory. David McDowall captures this sentiment when he says that 'it [Turkey] has an emotional and ideological view that its frontiers . . . cannot be changed without threatening the foundations of the Republic... The integrity of Turkey within its present borders has acquired an almost mystical quality for those faithful to the legacy of modern Turkey's 
founder, Mustafa Kemal Atatürk. As a result, the loss of Kurdistan, despite its poverty would be perceived as a grievous blow to the spatial identity of Turkey' (McDowall 1996: 7).

The borders of the new sovereign state to be set up within the Anatolian rectangle were first expressed in the National Pact (Misak-i Milli) of 1919-20 as the political mandate of the Turkish nationalist movement. The significance of the National Pact went beyond the putative intention to find a life-space for the remaining elements of the Empire. It embodied two dynamics: it endorsed the reality of the death of the Ottoman Empire through contraction, and yet it confined its territorial engineering to a 'new' sovereign state within a specific part of the imperial geography of the predecessor state. The National Pact, therefore, was a territorial programme for defining a new entity $v i s-\grave{a}-v i s$ the old one. But the old one was not just an entity to be disregarded, rejected and forgotten. The genesis of modern Turkish ideological developments and state formation had been, largely, within the ancien régime.

Indeed, late Ottoman nationalism was instrumental in the emergence of Republic's nationalism. But, the territorial factor significantly served to distinguish official Turkish nationalism from the late Ottoman version. The cultural pan-Turkism of the Young Turks as put forward by some pre-WWI statesmen and ideologues, envisaged a pan-Turkish unity with the various peoples of Central Asia and Caucasus on the bases of ethnic and Islamic criteria. By contrast, early Republican nationalism emphasized the modern concept of civic and social equality regardless of ethnic and religious origins, but they did not completely disown the racial and linguistic component advocated by the prominent theoretician of the Young Turk movement, Ziya Gökalp, who had elaborated some kind of a Turkified Islam as the best recipe for cohesion for the new nation (Lewis 1968: 359). Nor did the Republican concern to set up a secular nation-state 'eliminat[e] Islam from their definition of the concept of nation; in practice, . . they continued to give a certain consideration to religion.' (Dumont 1984: 30).

If differences between the foundational discourse of the Republic and late Ottoman nationalism were not 'as great as one might expect' (ibid) the most radical departure was on the issue of territory. Pan-Turkism and Islam as ideologies for unifying the mosaic structure of the Empire, 'were both nonterritorial; there was no country and no government in the existence defined by either of them' (Lewis 1968: 352), whereas the National Pact attached almost a sacred character to the post-imperial enclave of Anatolia. The 1935 programme of the People's Republican Party, which founded the Republic, declared that 'the fatherland is the sacred country within our present borders' (Kazancigil 1981: 51). 
The strong emphasis on the discourse of territorial identity was also the result of its worrisome lack of emotional appeal. Bernard Lewis reminds us of the lack of a name for Turkey in Turkish (Lewis 1968: 352). Indeed, the National Pact referred not to Turkey and Turks but to the areas inhabited by an Ottoman Muslim majority 'united in religion, in race and in aim' (ibid). Given the weakness of people's existence based on Turkishness, fostering loyalty to the territorial identity of the new construct of Turkey became the crucial underpinning of the Republic's nationalism, intruding into everyday life, penetrating into psyches, turning into an existentialist issue, a matter of life and death. Naming a territorial homeland preceded the formation of national consciousness and a collective conscience: the national territory preceded the nation.

The Turkish rectangle was, of course, portrayed as the cradle of a series of Anatolian civilizations culminating in the Turkish one. This historical geography was employed to delineate not only the external but also the ethnic boundaries of Turks, and to strengthen racial pride and cohesiveness. The Ottoman government had agreed, in the Treaty of Sevres (1920), signed with the Allied Powers, to provide for a Kurdish state. By the time the National Pact laid out the borders of the new state, the nationalist movement had gained sufficient momentum to dictate the conditions of the right-sizing of the Ottoman state to include the predominantly Kurdish areas lying in the eastern flanks of the Anatolian rectangle in Turkey. This claim was based on the Ottoman historical presence and heritage in the historical geography of the region. It was also prompted by political considerations to unite whatever Ottoman Muslim majority was left from the dismemberment process.

\section{Non-Negotiable Borders, National Identity, and the Question of Hegemony}

The Kurdish question contests the most critical assumptions of Turkish nationalist doctrine, especially the core principle that there are no identities in Turkey other than the one covered by Turkish national identity. Analysing this assumption offers a theoretical opportunity to link Turkish political identity to the imperatives of the developmental, political role of the 'modern' state and modern nationalisms. This is so, because, since the emergence of a global system of nation-states in the nineteenth and twentieth centuries, the dominant imagination of nationalisms, is, everywhere, the notion of modernity. From the outset, the construction of a homogenous national identity in Turkey was linked with the logic of catching up with the modern 
West. Modernity understood as Westernization was connected with economic prosperity and a strong state. A non-negotiable national identity was thought to secure the conditions of the existence of these two goals. Diversity and social pluralism were seen as obstacles to the emergence of a modern and strong state. The crucial point here is that a homogenous national identity became part of the attempt to extract recognition as a Western nation from the West. This meant that the 'power' dimension of the Republic became linked with Westernization, and demonstration of a homogenous national identity, in turn, had a key role in easing integration with the West on an equal basis.

Since, however, modernity also entails a discourse of democracy, rights, and equality of citizens, the goal of controlling the polity could not have been confined to the imperative of westernizing simply as strengthening the regime's ability to rule over a unified territory. On the domestic level, westernization was powerfully articulated with Rousseau's conception of Republicanism which stressed 'the centrality of obligations and duties to the public realm' and of 'the supreme direction of the general will, the publicly generated conception of the common good' (Held 1996: 56, 58). The political stratagem of the Kemalists was to reinforce these Rousseauist principles, by making general will the culmination of the political legitimacy based on popular sovereignty. Turkish democracy, in consequence, has not emphasized democratic legitimation of governments through their respect for the rule of law, civil society, and constitutionality. Instead, the ends of the state, the general will, have held priority above those of the rights of the individuals. Rule by the majority and electoral politics have become proof of the regime's allegiance to democracy.

The social and historical context of the Republic meant that the national identity was constructed as a hegemonic ideal at the level of culture and (westernized) civilization. It also acquired hegemonic significance for the state because of the weak articulation of this identity with demographic, social, and historical levels of the society. The national community, from the inauguration of the Republic, had to be constructed out of an embarrassing diversity of a demographic reality which was a legacy of the Ottoman mosaic. The confusing range of ethnic, linguistic, and sectarian attachments produced insecurities and anxieties over the question of the constituents of an identity in an inarticulate and uncertain social world.

Turkish nationalism was formally based on a total repudiation of the past political and cosmological configuration of the Ottoman Empire. However, the Ottoman historical legacy continued to shape the national consciousness, and Islam remained the chief marker of self-identification for the majority. This was particularly true of the Kurdish communal identity that had a 
long-entrenched association with the Khalidiya branch of the Naqshbandi tarikat-a Sufi brotherhood-dominant in the south-east. The new national identity stood a good chance of being accepted by the Ottoman Muslim population of the Republic if it made Islam the cultural norm of its discourse. But, contrary to the experience of the emergence of Balkan nationalisms, where the church joined forces with the secular élite in instilling a national consciousness against the Ottoman rulers, the Republic was more constrained in its choice of allies.

The legitimizing ethos of Turkish nationalism was not just independence but a total transformation of values in the direction of westernization, understood as the sole route to modernization. Secularism was the pillar, the principle, and the proof of this ethos. It meant disestablishment of Islam as the state religion, and making politics independent of religious considerations, including the religious heterodoxy prevalent among the population. But establishing a positive western-like self was impossible unless the negative and significant other, Islam, was present. In this sense, promotion of a European-like Turkishness has historically involved an open recognition of Islam as a crucial element of Turkish identity. In addition, the Ottoman state tradition of including the highest functionaries of Islam, the ulema, within the structure of the state eased the establishment of a similar set-up in the Republic. Establishment Islam became an instrument for articulating a national community. How the state sought to cope with Islam is beyond the scope of this essay. Suffice it to say that state-Islam interaction took a complicated and contingent trajectory over the life of the Republic. For our purposes here, the key problem of Turkish identity lay in developing it in such a way that it could match and overcome the power and salience of Islam. Competing against the stronger traditions and older institutions of Islam became a source of weakness for the attempt to establish the hegemony of the constructs known as Turkey and Turkishness.

Given the fact that the construct of Turkish national identity concealed profound contradictions and antinomies on sociological and historical levels, the Kurdish factor has historically assisted the consolidation and legitimation of state power through providing a testing ground for the Kemalists. As the hegemony of the modern state is made to depend on overcoming political and sociological fragmentation, some imagining of territory-wanting Kurds became instrumental for the master narrative of Turkish nationalism. In short, the imagining of Kurdish nationalism has served to unify the Turkish polity and provide some coherence to Turkish identity. This effect of Kurdish nationalism on Turkish homogeneity bears a striking parallel to the impact Islamism has on closing the ranks of secular minded Turks. In the final analysis, Turkish identity became a constitutive element in the legitima- 
tion of the political rule of the Republic. National integration and security became conflated and mutually reinforcing.

Countering and containing Kurdish ethno-cultural existence as distinct from the Turkish one was, then, intimately connected with the aspirations of the state to modernize (westernize) and the unsettled question of hegemony. Pluralism was regarded as disintegrative, sapping the strength of the nation, strength deemed to be essential to achieve with the West. This is the aspect of the Republic that sought to absorb heterogeneity into controlled modernity. Yet, the imperatives of nationalism also bear some responsibility for the definition of Turkish identity that was intolerant of differences. In that sense Turkish nationalism is hardly an aberrant form of nationalism: there is a 'profound dualism at the heart of every nationalism . . . every nationalism contains civic and ethnic elements in varying degree and different forms. Sometimes civic and territorial elements predominate, at the other times it is the ethnic and vernacular components' (Smith 1991: 13). It is this indeterminancy in the dual constituents of nationalism that produces 'the political power of nationalisms [ compared with] their philosophical poverty and even incoherence' (Anderson 1991: 5). Membership in a nation is not only defined by civic terms, but also involves participation in a common culture. The contrast between 'civic nationalism', used in the tradition of Hans Kohn to define a Western or modern nationalism as distinct from an 'Eastern' or nasty variety (Kohn 1969; Kohn 1982), is also applicable to the Turkish case. Turkish nationalism also contains two contrasting strands, one highlighting the ethnic singularity of Turkishness and the other that essentially grants equal citizenship rights to all those living on the Turkish territory regardless of their ethnic origin (Sakallı̈̆s lu 1996). Indeed, 'the problem is not that Turkey refuses to accept Kurds as Turkish citizens. The problem is precisely its attempt to force Kurds to see themselves as Turks' (Kymlicka 1996: 39) causing, in the process, a suppression of Kurdish historical memory, which in turn produces resentment and resistance.

This dual character of Turkish nationalism reflects the dual models that were simultaneously enforced for building Turkey's political identity since the genesis of the Republic. The first was 'civic integration . . creating a common civic, national or patriotic identity and citizenship' (McGarry and O'Leary 1994: 102), whereas the second 'assimilation as a model went further and favoured the merging of ethnic identities . . . into a new one' (ibid). As these two models of integration were based on a special understanding of democracy emphasizing the majoritarian logic of electoral politics rather than the 'limited state' concept of Western liberal tradition, their usage in Turkey could be turned into instruments of what McGarry and O'Leary describe as 'hegemonic control' (ibid: 106). 


\section{The Nation Made: Reshaping as Integration}

How did the official definition of national identity evolve in response to the changing needs of westernization, Kemalist hegemony, and Kurdish challenges? It is fair to suggest that for most of the republican history a homogenizing national identity remained elusive. Nationalism has acted as a conservative force denouncing different foci of loyalty to other than Turkish ethnicity, Sunni Islam, the Turkish language, and Turkish history as heresies. The reshaping of domestic democracy was conceived as, and articulated with, the strategies of national integration and promotion of national unity. National integration in particular was achieved through four basic conduits: electoral participation, military conscription, extensive primary school education, and infrastructural modernization.

Even in the single party period (1923-46), elections were held regularly. And during much of the cold war, Turkey's regular and open multi-party electoral democracy became the most effective means of limiting conflict and legitimating the process of national integration. Trans-community national parties enabled the Kurdish community to transcend narrow local interests and identify their problems with the global discourses of the age, be they capitalism, socialism, or social democracy. In the eyes of the governing élite the low level of threat posed by the Kurdish community was instrumental in ensuring that representative institutions were kept open to them. Compulsory military conscription and the development of a network of primary schools in the remote areas of the country provided some homogenizing experience and a sense of a common larger homeland. The republican progressive view of history dominant among Turkish minds held that traditional loyalties and modes of living could not withstand the onslaught of infrastructural modernization. It found expression in the capitalist integration of the predominantly Kurdish area of the south-east into the mainstream.

In sum, and despite the heritage of resentment within the Kurdish community for the subsumption of their identity within the Turkish national identity, economic modernization during the cold war era provided some shared interests, a degree of equality and a détente with the larger community. Kurdish nationalism was not yet capable of disturbing the status quo because it was confined to a small educated strata while the less modern and poorer groups were not articulate or mobilized: 'on the one hand, nationalism or at least some degree of Kurdishness constituted their (the Kurdish elites') common ground ... on the other hand, they were differentiated according to political cleavages that concerned Turkey as a whole ...' (Bozarslan 1996: 146). That they were able to sustain a double identity, rather 
than a single discourse committed to Kurdish nationalism, was because of the modicum of security and relative prosperity enjoyed by the Kurds. On the Turkish side, too, the tension between the Western and Islamic facets of national identity did not yet reach the stage of open contestation over what genuinely constituted a 'Turk.' Certainly, the evidence of the 1960s and 70s shows that neither Europeanization nor secularism have ever been clandestine and flimsy aspirations throughout the Republic. The territorial nationstate is popularly rooted and the settlement of 1919-20 is widely regarded as a permanent arrangement.

In the recent post-cold war era, this political configuration was shaken. Two developments have provided the momentum for a redefinition of the constitutive categories of Turkish identity with important implications for the Kurdish issue. First, official nationalism and almost all political poles on the ideological divide have embraced the agenda of a reduced state, popular capitalism, law and order, and global patterns of consumption and life styles. The second force that caused the establishment to reimagine Turkish identity is the ongoing crisis of the model of 'national capitalism' which caused a loss of clear and unambiguous loyalty to the state.

Intense penetrations of modern globalized artefacts and ideas have caused a renewed emphasis on the part of official nationalism on modern/Western aspects of Turkish identity. The old historical concern to gain respect from the West has resurrected itself in the intense struggle to become a member of the European Union. But while, under the global conditions, being considered modern became a central aspect of Turkish modernity and political identity, distinguishing her from the neighbouring countries, pride in the ethnic roots and Sunni Islam were also articulated in the definition of Turkish identity. The neo-conservative tone of the international politics, revival of Islamism, and the escalation of the Kurdish conflict since 1984 provided the impetus for this synthesis. The discourses of a long line of centreright politicians since the mid-1980s have identified Turkishness with Western values, albeit on a superficial level, as well as with the symbol of the flag, blood and sacrifice, Ezan (prayer), and Muslim morals. ${ }^{3}$

What increases the appeal of nationalism for the masses in a global age is the articulation it offers between modern/global values and parochial elements. Emphasizing their ethnic singularity under a global veneer, even the radical ultra-nationalist forces have achieved rehabilitation with the political centre. Political Islam, on the other hand, has become the main beneficiary of

3 The statements and speeches of the leader of the True Path Party (TPP), Tansu Ciller, who was the Prime Minister of a series of coalition governments formed between the TPP and the Social Democratic Populist Party between 1993-5 are the prime examples of this discourse - see Ciller $(1993: 13,62,95)$. 
the retreat of the state and the dislocation and disorientation caused by globalism, which are not addressed by the nation-state. Political Islam has put the Western/secular political identity of the Republic under intense pressure. Turkish national identity has become more contestable, but has it really become unambiguous and stable?

The escalation of Kurdish separatist militancy in the last decade and a half adds yet another important dimension to the above problematic, constituting, in Martin Kramer's words a 'violent reminder that Turkey has not achieved full integration as a homogenous nation-state of 'Turkish speakers' (Kramer 1997: 105). But surely, there is something even more important than this reminder: at certain conjunctures and under certain pressures, new articulations of national identity may become a key to maintaining the nonnegotiable character of the boundaries. There may be a democratic opportunity for developing a larger and genuinely inclusive vision of community, which can form the basis of a stable and healthy society.

Kurdish nationalism since 1987 owes much of its militancy to the transformation of official Turkish nationalism in the same period. In contrast with the cold war times when the physical conflict dimension of Kurdish nationalism was almost non-existent, the post-cold war momentum for Kurdish nationalism came from two sources: the force of the official redefinition of the Turkish nation with a strong dose of ethnic homogeneity and the process of global change. The official response to the radicalism of Kurdish nationalism has been to narrow the political space to Kurdish demands, which are now organized on the new basis of an 'identity claim'. This has led to a vicious circle: the political space for the expression of Kurdish identity, interests and ideas is restricted by the failure of traditional political parties in conveying and processing Kurdish demands, and by the closing down of exclusively Kurdish political parties by the Constitutional Court. ${ }^{4}$ This created new political opportunities for Kurdish radical nationalism in the 1990s, and at this point, we need to turn to the relevance and implications of the evolution of Kurdish articulations and rearticulations of national identity.

\section{Is Territory the Founding Logic of Kurdish Nationalism?}

Of the 20 to 25 million Kurds in the Middle East, some 12 to 14 million live in Turkey, and their current estimated regional concentrations are shown in

4 The first of the series was People's Labour Party - Turkish acronym being HEP — which was founded in March 1990. Being disbanded in July 1993, it was succeeded by Democracy Party (DEP). When this party was banned in June 1994, its place was taken by People's Democracy Party (HADEP). See also the discussion of coercive electoral integration by Brendan O'Leary in Chapter 2. 
TABLE 8.1. Estimated Kuridsh population, by region of Turkey

\begin{tabular}{|c|c|c|c|c|c|}
\hline \multirow[b]{2}{*}{ Region } & \multirow[b]{2}{*}{$\begin{array}{l}\text { Provinces in } \\
\text { each region }\end{array}$} & \multicolumn{2}{|l|}{1965} & \multicolumn{2}{|l|}{1990} \\
\hline & & $\begin{array}{l}\text { Number } \\
\text { (thousand) }\end{array}$ & $\begin{array}{l}\% \text { province } \\
\text { population }\end{array}$ & $\begin{array}{l}\text { Number } \\
\text { (thousand) }\end{array}$ & $\begin{array}{l}\% \text { province } \\
\text { population }\end{array}$ \\
\hline Marmara & 1 & 72.65 & 1.24 & 810.13 & 6.09 \\
\hline Aegean & 2 & 15.77 & 0.36 & 296.99 & 3.93 \\
\hline Mediterranean & 3 & 190.22 & 4.98 & 726.55 & 8.95 \\
\hline Central Anatolia & 4 & 262.64 & 4.13 & 579.38 & 5.53 \\
\hline Black Sea & 5 & 28.72 & 0.51 & 37.88 & 0.50 \\
\hline Eastern & 6 & $1,369.65$ & 38.87 & $2,230.29$ & 41.96 \\
\hline Southeastern & 7 & $1,192.73$ & 64.24 & $2,365.04$ & 64.98 \\
\hline $\begin{array}{l}\text { Total (\% of } \\
\text { total population) }\end{array}$ & & $3,132.39$ & 9.98 & $7,046.25$ & 12.60 \\
\hline
\end{tabular}

Sontre: Mutlu (1996)

Table 8.1. Historically, Kurds have existed throughout written history. The battle of Çaldıran in 1515 marked a watershed in their relationship with the Ottoman political rule: in return for military collaboration with the Ottoman rulers against the rising power of Shi'ism and Persian influence, the pact of Caldiran guaranteed political autonomy to the Kurds and confirmed the hereditary rights of their princes. The period of stability that followed in the region of what is today known as the south-east of Turkey was disrupted by a number of events, culminating in the destruction of the autonomy of the principalities by the centralization and modernization movement in the Ottoman Empire in the nineteenth century. After the defeat of the Empire at the end of World War I the Treaty of Sevres was signed in 1920. Kurds were promised a scheme of local autonomy for the predominantly Kurdish areas lying east of the Euphrates, and north of the frontier of Turkey with Syria and then-Mesopotamia, with an eventual independence-see Fig. 8.1 and see also the maps in Denise Natali's discussion of the Kurdish question in Iraq, Chapter 9. The Treaty of Sevres, however, was overturned by the Treaty of Lausanne in July 1923 that recognized the sovereignty of Turkey in accordance with the boundaries that Turkey had drawn for itself in the National Pact of 26 January 1920. From Lausanne on, Kurds found themselves living a fragmented existence in Turkey, Syria, Iraq, and Iran.

For various reasons, the question of whether or not Kurdish demands in Turkey contest the territorial framework of the Turkish state is difficult to answer. The issue of territory carries symbolic importance for the Kurdish imagination. The notion of 'Kurdistan' extends 'from the Black Sea near the 


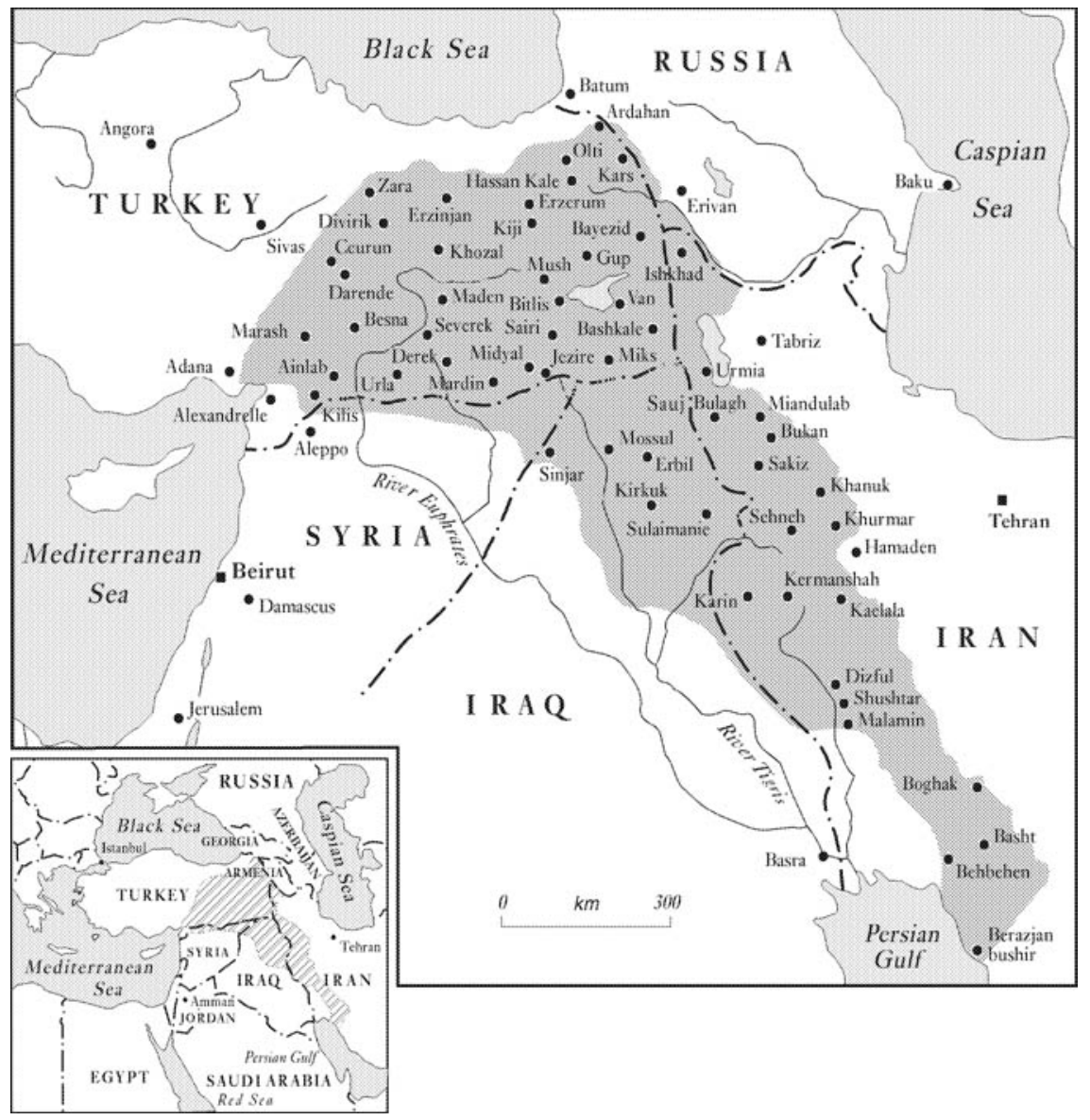

FIG. 8.2 Regions populated by the Kurds in the 1920 s

Caucasus to the Persian Gulf as well as the fertile plains to the West' (Andrews 1982: 17). ${ }^{5}$ Kurdish people have existed as a distinct group for more than two thousand years in the central part of that space: 'there is both a practical and mythical interpretation of political Kurdistan. The former affords Kurdistan the borders its political leadership either hopes or believes it can achieve' (McDowall 1996: 3). Borders that presently span over four states represent systems of domination for the divided Kurdish nationalist movements in these countries to challenge.

5 A more up-to-date imagination of Kurdistan would span an area extending from eastern Turkey to western Iran, northeastern tip of Syria and northern Iraq. 
Have these internationally recognized frontiers kept Kurdish populations apart to the extent of preventing Kurds from extending their emotional allegiance to a greater Kurdistan as 'the imagined homeland'? It can be suggested that 'frontiers have not been wholly disadvantageous to the Kurds' (ibid: 8 ) in that the permeability of these borders has always allowed a margin of movement for the Kurdish population by cutting across rather than along the linguistic-cultural divisions in Kurdish society (ibid). On the other hand, the diffusion of Kurds in four states has not prevented them from 'double adhesion to two separate entities; the first the state and the second the minority, itself supra-territorial in nature and extending beyond the limits of Turkish political geography' (Bozarslan 1996: 108).

Kurdish demands today are ambivalent messages expressed at different times by different agents and in different modes. On the level of the nationstate when the demands revolve around cultural rights, it is the ethnic singularity of Kurds which emerges as the conscious object. Again at the same level, when demands are centred on material entitlements, social improvement, and legal protection, this discourse is tilted toward a reference to the equality of Turkish citizens. When Kurdish intellectuals and political leaders address themselves to the international community, the discourse becomes adversarial and territorial, challenging the Turkish state on very many accounts. The contents of interviews with Abdullah Öcalan, the leader of the PKK, for example, show big differences depending on the audience. In March 1992, in an interview with a Turkish magazine, he said, 'the PKK is not inevitably insisting on organised violence . . our goal is not to divide Turkey, but to share it. ... I do not see it as either reasonable or necessary that a Kurdish region should be detached from the country as if cut by a knife ...' (Marcus 1983: 242). However, a month later, in an interview in the PKK's European-based magazine, he indicated that he 'had not given up his desire for a Kurdish independent state' (ibid: 243). In April 1998, after the weakening of the PKK as a result of the Turkish military's crackdown, Öcalan seemed to revert back to the message that the PKK does not want to break up the unity of Turkey, and that it would like to start a process of political dialogue with the Turkish state from which the PKK is presently excludedbecause of its political violence, and because the Turkish state does not recognize Kurdish political parties — and that all that Öcalan wanted was cultural and political rights. ${ }^{6}$

${ }^{6}$ This was reported in an interview by a Turkish daily with Prof. Michael Gunter on his return from a ten-hour interview he had himself conducted with Abdullah Öcalan in Damascus on 13-14 March 1998 (Congar 1998a, b). 


\section{The Evolution of the Basis of Kurdish Expressions}

Until the limited modernization project of the late Ottoman period was given full impetus in mid-twentieth-century Turkey, Islam was the principal public expression of Kurdish communal identity: the Khalidiya branch of Naqshbandi tarikat provided the central values and particular ways of thinking and behaving as a Kurd. Kurdish ethnic distinctions overlapped with Islam (Bruinessen 1992: 7). When the secularization policies of the early Republic shattered the power of tarikats by closing them, Islam for Turkey's Kurds turned into an 'identity of resistance' (Yavuz 1995: 355), witnessed in a series of revolts between 1925 and 1937.

However, a more substantial and partly voluntary integration of the Kurds into the mainstream in most of the cold war period enabled the Kurdish community to imagine its identity and social existence as less based on Islam and more on the discourses of the age: the emerging secular Kurdish intelligentsia interpreted Kurdishness from the perspective of the key theme of the Turkish political left, distributive justice, and civic and social rights (McDowall 1996: 211). And right-wing Turkish political parties recruited the remnants of the tribal leaders who subordinated their Kurdishness to the state's priorities. Some degree of party political and electoral integration was therefore feasible. In recent Turkish elections Kurds have not homogeneously voted as a bloc, and it would be difficult to tell if they had, but as can be seen in Table 8.2 it is absolutely plain that support for HADEP (Halkin Demokrasi Partisi/The People's Democracy Party), a pro-Kurdish party, in the 1990s was strongly and disproportionately concentrated in provinces with significant numbers of mother-tongue Kurdish speakers; and that participation rates in elections are lower in provinces with significant numbers of mother-tongue Kurdish speakers.

The most recent perspective that dominates the Kurdish nationalist discourse is 'identity'. According to one 1995 report carried out in three predominantly Kurdish provinces in the south-east - Diyarbakır, Batman, and Mardin - and in three provinces in the south which receive intense Kurdish migration-Adana, Mersin, and Antalya - in-depth interviews with one hundred opinion-leaders show that 40.3 per cent of the respondents refer to Kurdish ethnicity as the basis of their identity, while only 22.3 per cent selfidentify as Turkish. ${ }^{7}$ In yet another report published a year earlier, ${ }^{8}$ the percentage who consider themselves Turkish is 21.7 . But, when respondents who react to a Turkish identity by not giving any response ( 30.2 per cent) is

\footnotetext{
7 The report was sponsored by the Union of Turkish Chambers of Commerce and Stock Exchanges and published in July 1995.

${ }^{8}$ PIAR-GALLUP (1994: 14). See note 1 above.
} 
TABLE 8.2. Participation rates and distribution of voting for Kurdish-speaking provinces, ${ }^{a}$ $1991-1995$

\begin{tabular}{|c|c|c|c|c|c|c|}
\hline \multirow[b]{3}{*}{ Parties } & \multicolumn{6}{|c|}{ Election: average participation (\%) } \\
\hline & \multicolumn{2}{|c|}{1991 National } & \multicolumn{2}{|c|}{1994 Local } & \multicolumn{2}{|c|}{1995 National } \\
\hline & Turkey & 17 Provinces & Turkey & 18 Provinces & Turkey & 18 Provinces \\
\hline ANAP & 24.0 & 22.5 & 21.0 & 19.0 & 19.7 & 16.3 \\
\hline CHP & - & - & 4.6 & 2.8 & 10.7 & 5.7 \\
\hline DSP & 10.8 & 2.8 & 8.8 & 0.9 & 14.6 & 3.2 \\
\hline DYP & 27.0 & 20.8 & 21.4 & 22.1 & 19.2 & 16.2 \\
\hline HADEP & - & - & - & - & 4.2 & 19.5 \\
\hline MHP & - & - & 8.0 & 5.3 & 8.2 & 5.8 \\
\hline RP & 16.9 & 16.6 & 19.1 & 27.3 & 21.4 & 27.2 \\
\hline SHP & 20.8 & 33.7 & 13.6 & 14.2 & - & - \\
\hline Others & 0.4 & 0.6 & 3.2 & 6.0 & 1.6 & 2.6 \\
\hline Independent & 0.1 & 1.5 & 0.3 & 2.5 & 0.5 & 3.4 \\
\hline Participation & 83.9 & 80.2 & 92.2 & 87.1 & 85.2 & 79.9 \\
\hline
\end{tabular}

Key:

ANAP Anavatan Partisi (The Motherland Party) — Center Right

CHP Cumhuriyet Halk Partisi (The Republican People's Party) Center Left

DSP Demokratik Sol Parti (The Democratic Left Party)—Center Left

DYP Doru Yol Partisi (The True Party Party)—Center Right

HADEP Halkin Demokrasi Partisi (The People's Democracy Party)_Pro-Kurdish

MHP Milliyetçi Hareket Partisi (The Nationalist Action Party)—Turkish Ultranationalist

RP Refah Partisi (The Welfare Party)

SHP Sosyal Demokrat Halkii Parti (The Social Democratic Populist Party) —Center Left (United with CHP in 1994 and resumed its political life under CHP

${ }^{a}$ Kurdish-speaking provinces means those provinces where more than $15 \%$ of the population declared Kurdish as their mother tongue during the 1965 census.

Source: Kirișci and Winrow (1997: 142)

added to those who identify themselves simply as 'human beings' - without a national identity - $(34.9$ per cent) and as a Kurd ( 18.5 per cent), it becomes clear that an overwhelming percentage ( 83.6 percent) of Kurds do not consider themselves Turkish. The evidence shows that the official posture that suggests that 'there is no Kurdish problem ... Turkey has a terrorism problem' ${ }^{\text {' }}$ cannot be sustained. In reality, nothing in the past was as damaging to state-Kurdish relations as the identity issue. While the past demands of material entitlements could be met without upsetting the status quo, the current demand for the recognition of Kurdish identity challenges the pillar principle of the Republic that defines the nation as a homogenous identity

9 This is a statement made by President Demirel in 1997 (Demirel 1997). 
based on a common allegiance to being Turkish. One Kurdish political leader, Șerafettin Elçi, summarizes the new demand: 'Kurds demand the recognition of their identity. There are obviously rights derived from this identity ... the right to education in their language ... and the right to organize on the level of political parties and cultural institutions' (interview with Șerafettin Elçi 1995).

This is not to say that there are not a number of serious problems related to the substance of 'identity' and 'ethnic identity' in general. Suffice it to say that the usefulness of identity politics is limited at the outset by the nature of the object it tries to promote: since identities are plural and contextual, there is no good reason to confine the qualities that define identities to 'cultural' ones, nor can identities always be politically peaceful in terms of not excluding the others (Fierlbeck 1996: 20). Still, the real question is not whether a sense of Kurdishness exists; it does. The real issues are two: to translate an existing social reality into part of the public discourse that would keep Kurdish distinctions inside rather than outside Turkey, and to acknowledge that this assertion of identity need have nothing to do with the cultural history or the ethnic significance of Kurds. It has more to do with the larger political context which, by posing a political threat to the cultural freedoms of Kurds has helped to reconstruct their identity on a new basis, precisely because identities have the quality of being capable of being redefined in articulation with a changing historical environment. More correctly, keeping Kurdish distinctions inside Turkey is a search that is reflective of a much wider problem confronting many post-cold war liberal democracies in terms of their attempts to reconcile competing claims for self-defining identities within a unified entity. The logical policy implication here, too, is to develop a liberal, cosmopolitan thinking about civic nationalism rather than adopt non-unitary administrative formulae that might lead to the break up of the Republic.

Why is it ethnicity that has become the chief marker of identity at present? Structural explanations of the Kurdish question focus on the past state policies and overlook the crucial impact of two things that have shaped Kurdish nationalism over the last two decades: the ethnically oriented definition of Turkish identity and intrusion of global ideas and forces. It could be suggested that an uneven modernization of the south-east of Turkey, and the new ethnic turn of Turkish nationalism have provided the context that is receptive to global processes. That this global impetus is mostly on the changing status of territorial and mental boundaries has important implications for the problematic of this chapter. 


\section{Globalism and the Shift of Emphasis onto Internal Boundaries}

By way of a generalization, it is safe to suggest that with globalization 'boundaries carving up economic life are weakened, [while] the boundaries demarcating cultural and political life appear to be strengthened' (Blaney and Inayatullah 1996: 98). This is obviously linked to the crisis about the loss of state monopoly over the definition of the nation. Contestability of a unidimensional national identity and the emergence of identity politics to gain new rights to promote the constitutional recognition of already existing identities have become parts of the new debate on the redefinition of citizenship and establishment of multiculturalism. Even in the advanced and more democratic societies in the West, there is a steady erosion of the power of the state to attract citizenship loyalty and an intense criticism on the fault-line of the modern liberal state that turns a blind eye to plurality of cultural and social existences. Democracy has come to acquire new meanings associated with uncertainties of commonalities, heterogeneity of political spaces, and contestable foundations of shared understandings of lifestyles. The philosophical boundaries within the nation-states, in other words, have become as important as the external boundaries. Nation-states everywhere try to come to terms with 'the multiple meanings and purposes associated with sovereign boundaries' (Blaney and Inayatullah 1996: 98). This does not mean that the idea of state sovereignty has been abandoned, but that there is a new intellectual possibility for people all around the world to redefine their placecentredness as power relations around them have changed.

Coming back to the Kurdish expressions, it is clear that within the PKK, which has been involved in a bloody confrontation with the state security forces since 1984, the idea of setting up an independent Kurdish state in a classical territorial form is still very much alive. Although there is much popular support for the PKK, ${ }^{10}$ it is less rooted in the imaginary territorially

${ }^{10}$ Evidence from the TOBB report in 1995 shows that when questioned on various aspects of the PKK, significant portions of Kurds are either 'silent' or indicate their support for it through indirect ways: while 65.2 per cent did not answer the question on their kinship relations with those who joined the PKK; 25.5 per cent kept silent on the possible objectives of the PKK, and yet 29.9 per cent did not respond to the question why the Turkish Republic could not succeed in defeating the organization. Again a significant proportion ( 64 per cent) chose to remain silent when they were asked what policies of the PKK they approved of. On the question of whether the government will be able to succeed in wiping out the PKK, while around 10 per cent did not want to answer and 2.6 per cent did not know, an overwhelming proportion ( 76.8 per cent) of those who responded gave a negative answer. When asked what the objectives of the PKK are, 30.6 per cent connect it with 'cultural and political rights', while only 2.5 per cent with the goal of 'dividing the country and agitating', and 15.3 per cent with setting up an independent Kurdish state. But a more positive image of the PKK is also rejected: a mere 5.6 per cent link it with cultural, political, and human rights and democracy. See TOBB (1995: 18-20). 
sovereign Kurdish state than in the wish to break an unhappy status quo which has turned 3 million Kurds into refugees and cost 40 billion US dollars and around 20,000 lives on both sides. The incapacity of the Kurdish popular masses to think their way out of their everyday ordeal has not only made them vulnerable to the PKK, it has also paved the way to the entry of global ideas which focus on more democratic arrangements of internal boundaries. The end result of these conflicting pressures has been the use of trans-local and transnational ideas in which human rights, pluralism, cultural rights to education, and broadcasting in Kurdish have become central elements of Kurdish demands in recent years. By the end of 1997-8, however, mass sympathy for the PKK seems to have declined partly because of major military setbacks that the PKK had suffered at the hands of the Turkish army. The disintegration of the core of the PKK leadership militarily has come to mean the disintegration of the core of the PKK's support in the region, and the widespread belief that with the return of some normalcy to the region, it will be difficult for the PKK to keep up the same momentum among its support base. ${ }^{11}$

There are additional reasons to think that the idea of a sovereign Kurdish national territory has been demystified by transnational events. The leading researcher on Kurdish nationalism, Martin van Bruinessen, argues in his recent writings that one essential dimension of the reaffirmation of Kurdish identity has been increased contact and communication among the Kurds of different countries after the Gulf War of 1991 through population displacement (Bruinessen 1996). ${ }^{12}$ To van Bruinessen, these two developments have produced paradoxical results: they have reinforced the awareness of a 'common' Kurdish identity embracing all the Kurds in the region, while at the same time increasing the awareness of 'differences' between Kurds of the different states. The result has been the emergence of subnational groups among the Kurds, Alevis, and Zazas developing their separate Alevi Kurdish

11 Talking about their impressions of an army-organized media tour of the region in November 1997 , key journalists (columnists) of the country coming from diverse ideological convictions seemed to agree that as a result of the massive military defeat the PKK had suffered under a Turkish military offensive at the end of 1997 , the native population had already cooled off from the PKK, and that the local commanders were now taking advantage of the lull to gain the support of the impoverished Kurds by offering free medical care, humanitarian aid, food, clothes, and consumer goods. The media and the government have also started a campaign to lure businesspeople to the region by offering cheap loans and tax exemptions. For a representative sample of these impressions see Tinc (1997).

12 In the paper he presented at Princeton University on 22 April 1997, van Bruinessen repeated the same conclusion (Bruinessen 1997). The title of the paper he presented was a significant reminder of the dilemmas faced by the Kurdish identity, 'Kurdish Society in the 1990s: Caught between State, Religion, Nationalist Movement and Intra-Kurdish Ethnic identities'. 
nationalism and Zaza identities as distinguished from a comprehensive identity of Kurdishness.

\section{The Diasporic Dimension and Territory in Kurdish Nationalism}

One crucial factor that has contributed to the deterritorialization of Kurdish demands has been the transnational aspect of Kurdish nationalism that can be called its diasporic dimension. The escalation of the Kurdish conflict since early 1980s, and the consequent large-scale Kurdish migration to Western and Northern Europe, has created a transnational Kurdish movement connected with 'diasporic public spheres' (Appadurai 1997:4) in these countries, where Kurdish migrants, refugees, intellectuals, and exiles get involved in a 'long-distance nationalism' (ibid: 22). The interesting point about diasporic or long-distance nationalism is that, according to Appadurai, it operates less on the basis of 'territorial' aspirations than on '. . . the fear and hatred of its ethnic others' (ibid: 165), mainly because it is embroiled with the 'anguish of displacement, the nostalgia of exile, the repatriation of funds or the brutalities of asylum seeking' (ibid). Since this form of transnational nationalism only 'partially' revolves around the idea of a homeland as the substance of territorial affiliation, it is considered to be a 'revolution in the foundations of nationalism' (ibid: 161) which has crept on us 'virtually unnoticed' (ibid). For Stuart Hall as well, diaspora identity is a function of a specific diaspora experience which is mediated and transformed by memory, fantasy, and desire (Hall 1996: 163). Consequently there can be 'no simple return or recovery of the ancestral past which is not re-experienced through the categories of the present' (ibid).

Admittedly, as there is no scientific study made specifically on Kurdish diaspora communities in Europe, we do not have any hard data on the full nature of the Kurdish diasporic identity, and its articulation with territorial elements. On the basis of scant evidence, it seems that there are two conditions for ethnic communities of migrant workers in Europe to turn to homeoriented political goals: they are the establishment of ethnic enclaves which give impetus to the flourishing of lucrative ethnic business, and citizenship granting or denying policies of the host country (Abadan-Unat 1997: 229-51). The ambiguities that surround Kurdish diasporic nationalist aspirations partly stem from the activities of an important group of European-based Kurdish intellectuals who highlight non-territorial principles of solidarity and stressing communal commonalities. Whether they are 
representative remains to be seen. Technological devices, videos, and internet connections, and the enhanced interest in ethnicity and ethnic artefacts in the West have also been instrumental in highlighting the celebration of Kurdishness in many countries in Europe. Political propaganda and activism, with many supporters within native European populations, have enabled Kurdish causes to gain much sympathy and an important political space in Europe.

The ethnic mosaic of the Anatolian rectangle inherited from the Ottoman Empire has also made the fate of the two communities inextricable: there is a long history of intermarriage, shared political development, and lack of insulation of the two populations from each other. Neither Turkish nor Kurdish history exists in isolation. A Turkish factor has remained integral to the Kurdish sense of self, be it in the form of resentment and resistance, or affection and affinity. This may sound as little encouragement for the peaceful long-term resolution of the present conflict when one remembers over a million mixed marriages between Serbs, Bosnians, and Croatians before the burning of the Yugoslav state. However, the pessimism this fact evokes can be overcome when one remembers that 'it has been the absence of democratic institutions in Russia, the former Yugoslavia, Afghanistan, Somalia, Czechoslovakia and all the other disintegrating multicultural nations that aided and abetted tendencies to ethnic fragmentation and national solution' (Barber 1996: 144). The lesson that this quotation conveys alerts us to the idea that spatial containment of Kurds in the south-east has the potential of sharpening internal boundaries only in the absence of democracy and integrative mechanisms. With the ongoing armed conflict between the PKK and the state security forces causing poverty, hardship, unemployment, and homelessness among the Kurdish citizens of the Republic and the heavy military presence in the region which undermines normalcy, the mental borders between the two communities have been more sharply demarcated. Moreover, the ongoing feud between the Kurdish factions in Northern Iraq testifies to the bitter political divisions and competing loyalties among Kurds which, in the end, seriously hamper a shared idea and vision of a panKurdish state.

\section{Conclusion: e pluribus unum? 13}

This essay is an attempt to rethink the connections between the metaphor of boundaries as containers of democracy and the evolution of Turkish and 
Kurdish identities since the genesis of the Republic. It seems clear that the territorial question, more so for the Turks than the Kurds, is a functional spin-off of contentions that are substantially about power and hegemony in conditions of a historic trend toward social and cultural pluralism in an age of globalizing modernity. The rising appeal of ethnic Kurdish and Islamic fidelities are inextricably intertwined with Turkish nationalist commitments to territorial and political unity and consensuality.

It is important to recognize that neither national identity nor territorial nationalism are illegitimate, pathological, or outdated concepts. What is called into question is the kind of political imagination and understanding of power which sees national identity as 'the only form of life', far superior epistemically to any alternatives. Thus, the problem of nationalism can be solved and national identity can only survive if its meaning is limited: 'national identity, an important support of democratic institutions is best preserved by restricting its scope in favour of non-national identities' (Keane 1995: 201). The new principles of national unity and integrity are debated universally and there is an intellectual consensus that they should draw from the pluralities in the society. The tricky point is that political rights should not be based on cultural and social differences but on a special kind of sameness, rooted in universal principles of equality and freedom. In short, the discomfort and fear about the politics of community-based identities in Turkey can be eliminated when the question of identity is put on the table and analysed from a fresh perspective.

Wishful thinking aside, predictions regarding the future of a change in Turkey's public philosophy are unreliable. This is so because any new move toward establishing a multidimensional nationalism and public imagination requires two simultaneous changes which are difficult, to say the least: the first is 'catching up with' the 'modern' meaning of Western liberal democratic tradition which goes beyond majoritarian arithmetic, while the second is adoption of 'late-modern' components of democracy. Modern democracy presupposes an ethos of democratic legitimacy by which institutions and policies are accepted by even the minority as legitimate simply because they are democratic. The elements in this common conception of legitimacy are accountability and democratic control of the political class through the existence of robust civil institutions including political parties and the supremacy of the rule of law and constitutions. These procedural norms of modern liberal tradition are especially important for developing a critical public sphere for the representation of Kurdish views, and the discussion of new ideas on the Kurdish question without fear of state repression and for a greater public accountability of the public policies on the issue. Catching up with the 'modern' limited state offers possibilities of moderating the nationalist sentiments 
on both sides as well: ' $\ldots$ the common values arising out of, for example, union or parent-teacher association or political party membership ... Difference needs to be offset against common membership ... rather than being used as an argument for separation' (Barber 1996: 143-4).

In addition, there are post-modern realities in this late modern age that need to be addressed too by the Turkish political class. This is related to the task of drawing common political sentiments from a plurality of cultural and social existences. William E. Connolly (1993: 65) specifies the bases of a new understanding of democracy that democratizes territoriality and nationality in 'late-modern' conditions of uncertainties and paradoxes:

(1) promotion of an egalitarian constitution of cultural life;

(2) establishment of a not too strong sense of shared understandings; and

(3) initiation of a political culture in which a variety of constituencies respond affirmatively to uncertainties and diversities of late modern life by participating in the construction and reconstruction of their identities.

We need to be optimistic about the ability of the Republic to adopt 'modern' limitations of the state in order to adapt itself to a 'post-modern' international environment that, together with other variables, has led the Kurdish question to achieve its present status. E pluribus unum is the hope.

But are there concrete grounds for this hope to be realized? The contemporary reality of Turkish politics does not quite generate hopes for a new political wisdom that might easily replace the conventional. Nevertheless, two developments suggest that the unhappy status quo is not sustainable indefinitely. The first is related to the growing public awareness that what the Kurds want is what the larger society wants. It has become clear that a central aspect of the Kurdish issue is the conflict between those elements of the regime that advocate modern and post-modern reforms to establish a more open and accountable public space with full regard for the basic rights and freedoms, and those elements that have an interest in resisting these reforms. Curiously enough, it was a road accident on 3 November 1996 in Susurluk, a small township in north-western Turkey, that was instrumental in awakening the public's consciousness to this reality: the identity of the two passengers who died, and the one who was injured, revealed the existence of a criminal triangle of politicians, mafiosi, and security forces engaged in the war against the PKK. It seems clear that the state security forces have been systematically involved in black money laundering, drug-trafficking, and extra-judicial killings. The public anger at the 'Susurluk affair', as it came to be called, turned into an avalanche of societal pressure to reform the justice system, the police, and the bureaucracy, and they called into question the legitimacy of 
the security operations undertaken in the region in the last decades. Whether the full truth behind the Susurluk affair is ever established or not, the affair has helped to drive home the fact that the Kurdish issue is part of a broader challenge to the state to modernize and democratize itself amidst post-cold war realities.

Secondly, as it becomes clear that the Turkish military has dealt a serious blow to the core of the PKK, including the arresting and trying of its leader Ocalan, it is entirely within the discretion of Turkey's ruling class to move toward a new consensus, based on a more pluralist environment and improved local and national conditions. The power vacuum the PKK will leave behind in the region provides a visible incentive for prudent policymakers to create a new politics, to respond effectively and efficiently to the contemporary claims of self-defining identities. Life, in other words, is pushing for new solutions, making the ones devised ten or fifteen years ago completely outdated and defunct.

\section{Postscript: After the Capture and Trial of Abdullah Öcalan}

After the first draft of this chapter was completed in 1998, Abdullah Öcalan, who stood at the helm of the PKK for 20 years, first became a fugitive and then was captured by the Turkish security forces in Kenya on 15 February 1999. He was subsequently imprisoned in Turkey, tried, and sentenced to death on 29 June. The implications of his dramatic arrest and trial in a State Security Court on a prison island in the Sea of Marmara on charges of crimes against the state, have obvious bearings on the arguments advanced above.

The capture of its most-wanted man, held responsible for the deaths of 30,000 Turkish soldiers, fellow Kurds in the PKK, and civilians on both sides gave a tremendous boost to the self-defined image of the Turkish state. The election victories in April 1998 of the most nationalist Turkish platforms which refused to accept any compromise with Kurdish claims, were partly the result of the frustration and anger felt by Italy's refusal to extradite Öcalan and by the European calls for a fair trial. He had been detained in Rome in November 1998 after he was forced to leave his home base of 18 years, Syria, following an agreement between Turkey and Syria.

The Turkish government chose to use Öcalan's trial to 'teach' the democratic world that the PKK is a vicious terrorist organization, helped out by countries to its east and, most notably, to its west, in financing, training, and finding sanctuary for its members. Trying to embarrass the west by accusing its members of violating the fundamental rule and norm of 'international cooperation against terrorism' did not, however, serve the goal of bridging 
the gulf between the European Union and Turkey—widening partly because of European discomfort with Turkey's human rights violations. It did bring Turkey closer to the USA: following the American co-operation with the Turkish government in seizing Öcalan in Kenya, 'Turkish policy and opinion makers who until recently attacked Washington for planning to carve up a Kurdish state in the region, directed their anger at the European capitals and expressed gratitude for the American position' (Congar 1999: 46). Buoyed by strong American support and its developing strategic relationship with Israel, Ankara felt confident it could ride the storm within the European Union, including the pleas for clemency after Öcalan's death sentence. On the issue of comparison between the Kosovo Albanians and the Kurds, the Turkish government saw no parallel at all, despite its recognition of the persisting western image of Öcalan as a freedom fighter rather than as a bloody terrorist. Indeed, it indirectly holds the west responsible for much of the bloodshed in Turkey. Ankara's posture toward the Nato intervention in Kosovo-in the name of human rights and humanitarian imperatives-actually sought to draw strength from the controversy surrounding many aspects of the intervention.

Presently the arrest and trial of Öcalan does not seem to augur any significant new opening towards a reconciliation between the Turkish government and Kurdish secessionists. On the contrary, the arrest and trial have been used to reinforce the firmly held official conviction that there is no Kurdish problem but a problem of terrorism that could never have reached such explosive levels without external support. In the perspectives of the establishment and the large segments of the public, the arguments promoted for some time by liberals to the effect that the 'military solution' was bound to fail to stop violence and that what was needed was an overall democratization programme to undermine the PKK's support among the Kurds, have been proved to be invalid, indeed senseless. The liberal advocacy of a critical public sphere for the representation of Kurdish voices, Kurdish language teaching, and Kurdish broadcasting has been dismissed .

Öcalan's rather repentant posture during his trial and his 'moderate' sounding testimony aimed at politicizing the Kurdish question, and at sending different messages to different audiences. Speaking to the European gallery he seemed to be saying that he has now moved to a non-violent discourse and reduced his ambitions to the recognition by the Turkish state of the existence of a separate Kurdish entity within the 'unitary' framework of the constitution, abandoning Kurdish sovereignty aspirations altogether. The implication is that he should now be even more worthy of European support as a peaceful and representative leader, capable of engaging the Turkish government on this new agenda: that his life, that of an indispensable leader, 
should be spared so that he could mediate a political settlement between the PKK and the Turkish government and thus bring peace.

Within the Kurdish diaspora, however, Öcalan's arrest and trial seems to have had a divisive effect. There are those whose loyalty to the PKK and to the cause of Kurdish independence has hardened because of what they feel has been the unfair treatment Öcalan suffered from European hands which refused to grant him safe sanctuary, and, of course, from the Turkish government. Some diasporic elements, by contrast, appear to have sensed that Öcalan's capture and trial have delivered a major blow to Kurdish nationalism for many years to come. They can be expected to move toward a new search for a peaceful solution to the problem, needless to say, in a yet unclear way. In both tendencies, the centre of their activity has definitely shifted to Europe, which suggests a further internationalization of the Kurdish question that will upset any Turkish governmental calculation that the issue has definitively been resolved.

As regards the PKK, Öcalan's capture, trial, and testimony highlighted the congenital weaknesses of the organization's murky ideology, repressive leadership, and ruthless methods. Öcalan offered his services to the Turkish state to bring down the PKK members from the mountains in three months time if given the chance, that is, if his life would be spared (CNN 1999). His summing up speech emphasized the objections he had raised within the PKK from 1987 to mid-1990s, to its strategies on the grounds that 'these acts of violence were destroying us' (Milliyet, 23 June 1999). The speech made visible a gross contradiction between his self-claimed authority to be able to turn the PKK into a peaceful organization in a period of three months, and his confession of his failure to do so in the past. The new wave of violence that the PKK started in major cities after Öcalan's arrest does not add credibility to his openly expressed 'wish' to end the conflict through peaceful methods either. The interpretation that the PKK is simply following the leaders' promise to the Turkish government that was conditional on his life being spared, or the view that there is a leadership struggle within the PKK that presently clouds the formation of clear cut strategy, hold no sway against the popular Turkish belief that violence is the only language the PKK has known since its genesis.

The big question is whether the legacy of insensitivity, violence, and mistrust on both sides, that has plagued the south-east of Turkey for a very long time, will give way to a constructive dialogue. This depends on the extent to which both sides can go through a 'learning' process in a democratic direction, as opposed to a 'teaching' the other side a lesson. The prospects right now are not bright. 


\section{REFERENCES}

Abadan-Unat, Nermin. 1997. 'Ethnic Business, Ethnic Communities, and EthnoPolitics among Turks in Europe' in Immigration into Western Societies: Problems and Politics, edited by Emek M. Uncarer and Donald J. Puchala. London, Washington, DC: Pinter.

Anderson, Benedict. 1991. Imagined Communities: Reflections on the Origins and Spread of Nationalism. London: Verso.

Andrews, F. David (ed.). 1982. The Lost Peoples of the Mildle East. Salisbury: Documentary Publications.

Appadurai, Arjun. 1997. Modernity at Large. Minneapolis, MN: University of Minnesota Press.

Barber, Benjamin R. 1996. 'Multiculturalism between Individuality and Community: Chasm or Bridge?' in Liberal Modernism and Democratic Individuality; George Kateb and the Practices of Politics, edited by Austin Sarat, and Dana R. Villa. Princeton, NJ: Princeton University Press.

Blaney, David L., and Inayatullah, Naeem. 1996. 'A Problem with Borders' in Perspectives on Third-World Sovereignty, edited by Mark E. Denham and Mark Owen Lombardi. Basingstoke: Macmillan.

Bozarslan, Hamit. 1996. 'Political Crisis and the Kurdish Issue in Turkey' in The

Kurdish Nationalist Movement in the 1990s, edited by Robert Olson. Lexington,

KY: The University Press of Kentucky.

Bruinessen, Martin van. 1992. Agha, Shaikh and State: The Social and Political Structure of Kurdistan. London and New Jersey: Zed Books.

1996. 'Multiple Shifting Identities: The Kurds, Turkey, and Europe', Conference on Redefining the Nation, State and the Citizen, Marmara University, Istanbul, Turkey, 28-29 March.

1997. 'Kurdish Society in the 1990s: Caught between State, Religion, Nationalist Movement and Intra-Kurdish Ethnic Identities'. Paper presented at Princeton University, Princeton, NJ, 22 April.

Chaliand, Gerard (ed.). 1980. People Without a Country: The Kurds and Kurdistan. London: Zed Press.

Çiller, Tansu. 1993. DYP Genel Başkan Tansu Ciller'in Konuşmaları: 19 Haziran-5 Kastm 1993 (The Speeches of the True Path Party Leader and Prime Minister Tansu Ciller: 19 June-5 November 1993). Ankara: Başbakanlık Basım Merkezi.

CNN. 1999. 'Öcalan Pleads for a Chance to Make Peace with Turkey', CNN Interactive Web Site, 31 May 1999.

Congar, Yasemin. 1998a. 'Apo'nun Șam Villaları' (Apo's Villas in Damascus), Milliyet, 26 March.

1998b. 'Mektup Bekliyor' (Waiting for a Letter). Milliyet, 12 April. 1999. 'Do You Understand What I'm Saying?' Private Viem. 3: 40-6.

Connolly, William E. 1993. 'Democracy and Territoriality' in Reimagining the Nation, edited by Marjorie Ringrose and Adam J. Lerner. Buckingham: Open University Press. 
Demirel, Süleyman. 1997. 'Irk ve Din Partisi Olmaz' (There Cannot be a Party of Race and Religion). Hüriyet, 11 September.

Dumont, Paul. 1984. 'The Origins of Kemalist Ideology' in Atatürk and the Modernization of Turkey, edited by Jacob M. Landau. Boulder, CO: Westview Press.

Fierlbeck, Katherine. 1996. 'The Ambivalent Potential of Cultural Identity', Canadian Joumal of Political Science, 1: 3-22.

Hall, Stuart. 1996. 'The New Ethnicities' in Ethnicity, edited by John Hutchinson and Anthony D. Smith. Oxford: Oxford University Press.

Held, David. 1996. Models of Democracy. Stanford, CA: Stanford University Press.

Hürriyet. 1995. Interview with Șerafettin Elçi.'Turkey is Ours', 26 March.

Kazancigil, Ali. 1981. 'The Ottoman-Turkish State and Kemalism' in Atatük - The Founder of a Modern State, edited by Ergun Özbudun and Ali Kazancigil. London: Hurst.

Keane, John. 1995. 'Nations, Nationalism and European Citizens' in Notions of Nationalism, edited by Sukumar Periwal. Budapest, London, and New York, NY: Central European University Press.

Kinzer, Stephen. 1997. 'Kurdish Rebels in 'Turkey Are Down but Not Out', New York Times, 8 March.

Kirişci, Kemal, and Winrow, Gareth M. 1997. The Kurdish Question and Turkey: An Example of a Trans-state Ethnic Conflict. London, Portland, OR: Frank Cass.

Kohn, Hans. 1969. A History of Nationalism in the East. Grosse Pointe, MI: Scholarly Press.

(1982). Nationalism, its Meaning and History. Malabar, Fla: Krieger.

Kramer, Martin, 1997. 'The Middle East, Old and New', Daedalus, 2: 89-112.

Kymlicka, Will. 1995. 'Misunderstanding Nationalism', Dissent (Winter, 1995): $130-7$.

Lewis, Bernard. 1968. The Emergence of Modern Turkey. Oxford: Oxford University Press.

Lustick, Ian S., and O'Leary, Brendan. 1997. 'Rightsizing the State: The Politics of Moving Borders: Theoretical Guidelines for the Participants of Social Science Research Council Workshop 1997', unpublished manuscript, 29 February.

Marcus, Aliza. 1993. 'Turkey's Kurds After the Gulf War: A Report from the Southeast' in People Without a Country: The Kurds and Kurdistan, edited by Gerard Chaliand. New York, NY: Olive Branch Press.

McDowall, David. 1996. A Modern History of the Kurds. London: I. B. Tauris.

McGarry, John, and O'Leary, Brendan. 1994. 'The Political Regulation of National and Ethnic Conflict', Parliamentary Affairs, 46: 94-117.

Mutlu, Servet. 1996. 'Ethnic Kurds in Turkey: A Demographic Study', International Journal of Middle Eastern Studies, 28: 517-41.

PIAR-GALLUP. 1994. 'Kürt Araştırması'. Istanbul: Piar-Gallup. 29 September25 October 1994.

Poggi, Gianfranco. 1990. The State: Its Nature, Development and Prospects. Oxford: Polity. 


\section{$252 \ddot{U}$ mit Cizre}

Sakallı̈口 lu, Ümit Cizre. 1996. 'Historicizing the Present and Problematizing the Future of the Kurdish Problem: A Critique of the TOBB Report on the Eastern Question', New Perspectives on Turkey, 14: 1-22.

Smith, Anthony D. 1991. National Identity. Harmondsworth: Penguin.

Tinc, Ferai. 1997. 'Güneyd u Gezisinin Ardından' (After the Southeastern Tour), Hürriyet, 23 November.

TOBB. 1995. 'D ̊̆ u Sorunu-Teşhisler ve Tespitler'. Ankara: TOBB (Union of Turkish Chambers of Commerce and Stock Exchange). July.

Wolin, Sheldon. 1996. 'Fugitive Democracy' in Democracy and Difference: Contesting the Boundaries of the Political, edited by Seyla Benhabib. Princeton, NJ: Princeton University Press.

Yavuz, Hakan. 1995. 'The Patterns of Political Islamic identity: Dynamics of National and Transnational Loyalties and Identities', Central Asian Survey, 3. 